\title{
ОПРЕДЕЛЕНИЕ МЫШЬЯКА В СНЕЖНОМ ПОКРОВЕ
}

\section{Г. БАРНАУЛА МЕТОДОМ ВОЛЬТАМПЕРОМЕТРИИ}

Колесникова Т.И. ${ }^{1,2}$, Пантюхина Д. О. ${ }^{1,2}$, Темерев С. В. ${ }^{1}$

${ }_{1}^{1}$ ФББУ ВПО Алтайский государственный университет, Барнаул, Россия

${ }^{2}$ Институт химии и химико- фармацевтических технологий, Барнаул, Россия

kolesnikova.ccc@mail.ru

DOI: 10.26902/ASFE-11_162

Метод инверсионной вольтамперометрии использован для анализа мышьяка в образцах снега, взятых в марте 2021 года на территории Барнаула. Снеговые керны отбирали в период максимального снегонакопления методом «конверта» по $5-10$ кернов в каждой точке экологического мониторинга. Затем керны объединяли, перемешивали и взвешивали на технических весах. Далее образцы снежной массы таяли при комнатной температуре и фильтровали в атмосфере аргона через трековые мембраны, предварительно взвешенные на аналитических весах. Фильтраты подкисляли хлороводородной кислотой до рН менее 2,0. Фильтры с твердыми частицами снега выдерживали до постоянной массы под ИК лампой. Фильтрат и осадок анализировали отдельно. Фильтрат анализировали с помощью Аuрабочего электрода и анализатора ЭКОТЕСТ ВА (Москва). Сорбированные твердой компонентой снега формы мышьяка десорбировали смесью минеральных кислот серной, азотной хлороводородной.

Результаты химического анализа водорастворимых и десорбированных в кислотный минерализат форм мышьяка представлены в таблице 1.

Содержание мышьяка в снеговых талых водах использовано для расчета химической нагрузки на русловую сеть Оби в период снегового паводка 2021 года.

Таблица 1 - Концентрация мышьяка в компонентах снега

\begin{tabular}{|c|c|c|}
\hline \multirow{2}{*}{ Точка отбора } & \multicolumn{2}{|c|}{ Концентрация Ал (мкг/мл) } \\
\cline { 2 - 3 } & Фильтрат & $\begin{array}{c}\text { Кислотный минерализат } \\
\text { (пересчет с учетом мутности) }\end{array}$ \\
\hline Ж.Д.Вокзал & $(3,40 \pm 0,03)$ мкг/мл & $(5,70 \pm 0,02)$ мкг/мл \\
\hline ТРЦ «Galaху» & $(2,38 \pm 0,01)$ мкг/мл & $(14,0 \pm 0,05)$ мкг/мл \\
\hline Набережная р. Барнаулки & $(2,00 \pm 0,01)$ мкг/мл & $(9,75 \pm 0,05)$ мкг/мл \\
\hline
\end{tabular}

